Article

\title{
Irrigated Agriculture and the Cost Recovery Principle of Water Services: Assessment and Discussion of the Case of the Guadalquivir River Basin (Spain)
}

\author{
Alfonso Expósito \\ Department of Economic Analysis, Universidad de Sevilla, 41018 Sevilla, Spain; aexposito@us.es; \\ Tel.: +34-656-626953
}

Received: 13 August 2018; Accepted: 26 September 2018; Published: 27 September 2018

\begin{abstract}
The Cost Recovery Principle (CRP) is considered by the European Union (EU) water policy as a substantial requirement for economic efficiency, transparency, fairness, and sustainability in the use of water resources. Nevertheless, the implementation of the CRP by EU Member States has encountered significant challenges, both theoretical and practical, especially regarding the accounting of environmental and resource costs related to water use by the agricultural sector. This paper aims to analyse the application of the CRP to the agricultural irrigation sector in Spain, based on the case study of the Guadalquivir River Basin. To this end, an assessment of the financial, environmental, and resource costs (and the corresponding cost recovery rates) of water services related to the irrigation sector was carried out for this specific river basin. Additionally, this study aimed to offer a much-needed discussion on the agricultural "exceptionalism" phenomenon regarding the application of the CRP at the moment when water and agricultural EU policies are being reviewed to guarantee a more sustainable development of agriculture when using such a strategic natural resource.
\end{abstract}

Keywords: irrigated agriculture; cost recovery principle; environmental cost; resource cost; water pricing; Spain

\section{Introduction}

Irrigated agriculture constitutes the main user of water resources in Europe [1], although water costs in this sector remain generally low or negligible in comparison to those supported by other water-service users [2]. This mismatch leads to allocative and equity inefficiencies [3], as water prices lose their potential to inform irrigators about the complete cost of their water consumption and the external costs of their activities, such as the deterioration of water quality [4]. In this respect, the Cost Recovery Principle (CRP) is considered by the European Union (EU) water policy as a substantial requirement for economic efficiency and transparency in the use of water resources [5], but is also considered for fairness and sustainability reasons [6]. Consequently, most EU Member States (MS) are making certain advances in reforming their water pricing and financing policies towards higher cost recovery rates in all water services, including those of the agricultural sector. Nevertheless, these efforts remain insufficient [3,7]. Additionally, the implementation of the CRP by EU Member States (MS) has encountered significant challenges, both theoretical and practical, especially regarding the accounting of environmental and resource costs [8]. Although the analysis of the environmental external costs associated to agriculture has been addressed by extensive literature (see $[9,10]$, among others), its evaluation, together with the assessment of resource costs, has been limited [11].

The EU Water Framework Directive (WFD) 2000/60/EC [12] requires all economic costs of water services to be taken into account as an economic instrument to achieve a "good status" for all bodies of water. These costs include financial costs (which are basically operation, maintenance, and capital costs 
of water service infrastructure), environmental costs (defined as the costs of environmental damage imposed by water users, such as agricultural diffuse pollution), and resource costs (representing costs related to foregone use opportunities due to resource depletion). Nevertheless, existing cost-recovery data on the agricultural sector at EU level shows that this sector may be contributing insufficiently to cover the costs associated to its use of water services [3]. This factor, together with other exceptional treatments such as publicly subsidised modernization of irrigation systems, has led to irrigated agriculture in Europe (and in other parts of the world) to be described as enjoying exceptional treatment by governments with respect to other sectors under a presumed social legitimation [13-15]. This study focuses on irrigated agriculture as a water service beneficiary submitted to the fulfilment of the CRP, as defined by the WFD. Despite the expected reduction in the "exceptional" treatment of the agricultural sector regarding this principle due to new and reformed legislation in the EU (e.g., debates regarding forthcoming reforms of the WFD and CAP), which aims to include additional requirements for agricultural activities regarding both water pricing and internalisation of environmental external costs [14], further research and public discussion on the fulfilment of EU water policy principles remain scarce [16].

This study aimed to analyse the application of the CRP to the agricultural irrigation sector in Spain based on the information available regarding cost recovery in the Spanish River Basin Management Plans (RBMPs) (second cycle, 2016-2021). Furthermore, the case study of the Guadalquivir River Basin (GRB) was assessed in detail with the aim of offering an estimation of the financial, environmental, and resource costs (and corresponding cost recovery rates) based on the information contained in the last Guadalquivir RBMP [17]. Therefore, the aim of this paper is twofold. On the one hand, it aims to assess the implementation of the CRP in the irrigation sector of the GRB since this case study constitutes a good example of a closed river basin in a semi-arid region of the Mediterranean. The GRB has undergone an intense development of irrigated agriculture in recent decades, thereby imposing significant increasing pressure on available water resources. Furthermore, it is one of the most important Spanish river basins in terms of size, gross value added (GVA), and agricultural development: its assessment is therefore expected to be of relevance to other Mediterranean basins in Europe. On the other hand, it aims to offer a much-needed discussion about the agricultural "exceptionalism" phenomenon regarding the application of the CRP to used water services, at the moment when water and agricultural EU policies are being reviewed, to guarantee a more sustainable development of agriculture when using such a strategic natural resource. At this point, it is worth mentioning that this paper aims not to take a position in the political debate on agricultural "exceptionalism", but instead to contribute towards its analysis and discussion.

The rest of the paper is organised as follows. Section 2 offers an overview of the application of the CRP in the EU and Spanish context. Section 3 analyses the case study of the GRB and offers an evaluation of the CRP based on the assessment of financial, environmental, and resource costs. A discussion of the results and their policy implications are offered in Section 4. Finally, the conclusions are summarised in Section 5.

\section{The Application of the CRP in the Irrigation Sector}

Before the analysis of the case study of the GRB, this section aims to offer a brief review of the application of the CRP to the irrigation sector in the EU context, especially in southern EU member states, and in the Spanish context in particular.

\subsection{EU Context}

The WFD defines water services as "all services, which provide, for households, public institutions or any economic activity: (a) Abstraction, impoundment, storage, treatment and distribution of surface water or groundwater, (b) Wastewater collection and treatment facilities, which subsequently discharge into surface water." (Art.2 [12]). Therefore, water use means water services together with any other activity having a significant impact on the status of water. In general, water users, such as the 
agricultural sector, include water service beneficiaries, such as irrigated agriculture. Moreover, Article 9 of the WFD clearly obliges MS to "take account of the principle of recovery of the costs of water services, including environmental and resource costs ( ... ) in accordance with the polluter pays principle". Thus, MS must "provide incentives for users to use water resources efficiently, and thereby contribute to the environmental objectives of the Directive". Additionally, MS are to ensure an "adequate contribution of the different water uses, disaggregated into at least industry, household, and agriculture, to the recovery of the costs of water services". The implementation of the WFD by MS has triggered a real shift in the paradigm of European water policy since it positioned the effective implementation of the CRP as a necessary economic and legal principle to guarantee the achievement of environmental objectives. In this respect, guidelines to address the CRP in water services and the use of instruments for cost recovery purposes were also developed [18]. MS should have achieved a "good" status in all bodies of surface water and groundwater by 2015 unless there were grounds for derogation. Only in this case may the achievement of good status be extended to 2021, or to 2027 at the latest. Unfortunately, far from being exceptions, derogations have been the general case in most EU bodies of water $[19,20]$, whereby the existence of environmental damage caused by the agricultural sector constitutes one of the main reasons [21,22].

The agricultural contribution towards the cost recovery of water services varies depending on the country under consideration. Although data remain scarce, Table 1 attempts to show this heterogeneity among southern EU MS (where irrigated agriculture carries a significant weight as water user), both regarding cost-recovery (CR) rates (fifth column) and the assessment of environmental cost (EC) and resource cost (RC) associated to agriculture in the RBMPs (sixth and seventh columns, respectively).

Table 1. Water provision charges and CR in agriculture for certain EU countries.

\begin{tabular}{|c|c|c|c|c|c|c|}
\hline Country & $\begin{array}{c}\text { Agricultural } \\
\text { Withdrawals (\% Total) }\end{array}$ & Type of Charge & $\begin{array}{c}\text { Average } \\
\text { Irrigation Tariffs }\end{array}$ & CR Rate & EC & RC \\
\hline France $^{1}$ & 20 & $\begin{array}{l}\text { Water tariff (all-in) } \\
\text { Water tariff (dual) }\end{array}$ & $\begin{array}{c}0.09 \mathrm{EUR} / \mathrm{m}^{3} \\
80-160 \mathrm{EUR} / \mathrm{ha}+ \\
0.06-0.08 \mathrm{EUR} / \mathrm{m}^{3}\end{array}$ & $95 \% *$ & No & No \\
\hline Spain $^{2}$ & 70 & $\begin{array}{l}\text { Water tariff (volumetric) } \\
\text { Water fee (flat-rate) }\end{array}$ & $\begin{array}{c}0.064 \mathrm{EUR} / \mathrm{m}^{3} \\
113-470 \mathrm{EUR} / \mathrm{ha}\end{array}$ & $62 \%$ & Yes & No \\
\hline Greece $^{3}$ & 87 & $\begin{array}{l}\text { Water tariff (volumetric) } \\
\text { Water fee (flat-rate) }\end{array}$ & $\begin{array}{c}0.05-0.7 \mathrm{EUR} / \mathrm{m}^{3} \\
90-210 \mathrm{EUR} / \mathrm{ha}\end{array}$ & $54 \%$ & Yes & Yes \\
\hline Italy $^{1}$ & 44 & $\begin{array}{l}\text { Water tariff (volumetric) } \\
\text { Water fee (flat-rate) }\end{array}$ & $\begin{array}{c}0.04-0.25 \mathrm{EUR} / \mathrm{m}^{3} \\
30-150 \mathrm{EUR} / \mathrm{ha}\end{array}$ & $50 \%$ & Yes & No \\
\hline Portugal $^{1}$ & 80 & $\begin{array}{l}\text { Water tariff (volumetric) } \\
\text { Water fee (flat-rate) }\end{array}$ & $\begin{array}{l}0.002 \mathrm{EUR} / \mathrm{m}^{3} \\
120 \mathrm{EUR} / \mathrm{ha}\end{array}$ & $23 \%$ & Yes & No \\
\hline
\end{tabular}

Note: ${ }^{*}$ Includes all sectors. Sources: ${ }^{1}[23],{ }^{2}[17],{ }^{3}[24]$.

The insufficient cost recovery rate achieved in southern EU MS is due to various factors. In this respect, several studies show that the implementation of the Programme of Measures (PoMs) in river basin districts (RBDs) across the EU has revealed that transparent implementation of the CRP in the irrigated agricultural sector is not applied largely due to the lack of metering $[24,25]$ and socio-political factors [8]. Socio-political factors are normally based on two main arguments: environmental benefits provided by agriculture (e.g., rural landscape protection and provision of ecosystem services), and sector competitiveness [16,19]. In this respect, Cornish et al. [26] argued that this lack of political will is giving wrong signals to farmers as water users and thus endangering the achievement of WFD goals. For instance, French households consume $24 \%$ of billed water and contribute an average of $80 \%$ to the financing of measures aimed at reducing agrochemical pollution in water bodies, whereas agriculture uses $48 \%$ of billed water and contributes barely $2 \%$ [27]. Furthermore, even though EU water law addresses a good number of exemption clauses with respect to the application of the CRP (and other water policy principles such as the polluter pays principle), the politics of exemptions has been largely ignored in the literature [16]. 


\subsection{Spanish Context}

The WFD has been incorporated into the Spanish legal framework by Law 62/2003 (and its subsequent modifications by Law 11/2005 and Royal Decree 4/2007), together with a new Act for Hydrological Planning (Royal Decree 907/2007) and the Water Planning Instructions (Ministerial Order ARM/2656/2008). These legal pieces have transposed all EU water policy principles into the national legal framework, including the CRP as described in the WFD. In most cases, hydrological planning is a competence of the national government, which is implemented by River Basin Authorities. Nevertheless, in certain specific cases, such as Catalonian RBs and the Mediterranean Andalusian RB, development and implementation of water policy has been transferred to regional governments in fulfilment of legal frameworks of the EU and national water. Recovery cost instruments can thus be developed by national or regional authorities, or by both levels, depending on each RB. The specific case of the GRB constitutes an example of centrally managed RB with the RBA (central government) as the main governing and managing authority.

In a similar way to that of the EU, the Spanish context in terms of agricultural development in RBDs presents high heterogeneity. The significance of irrigated agriculture is higher in Mediterranean areas, where the Ebro, Guadalquivir, Guadiana, Jucar, and Segura RBs represent good examples. Table 2 shows data regarding the importance of the agricultural sector in each of these RBs and across the whole of Spain. In terms of water use, agriculture constitutes the main user in all RBs (as well as in Spain, as a whole), although in terms of GVA generation and productivity (EUR $\left./ \mathrm{m}^{3}\right)$, the differences between the selected RBs are significant depending on the type of crops cultivated and their irrigation needs. Nevertheless, agricultural water productivity is generally very low compared to that of industry $\left(131 \mathrm{EUR} / \mathrm{m}^{3}\right)$ and the urban sector $\left(156 \mathrm{EUR} / \mathrm{m}^{3}\right)$ [28].

Table 2. Agricultural water use, GVA and productivity in Spanish RBDs (2012).

\begin{tabular}{lcccc}
\hline & \multicolumn{2}{c}{ Water use } & GVA & Productivity \\
\hline RBD & $\mathbf{H m}^{\mathbf{3}}$ & \% Total & \% Total & $\mathbf{( € / \mathbf { m } ^ { \mathbf { 3 } } )}$ \\
\hline Ebro & 5085 & 97.2 & 3.1 & 0.46 \\
Guadalquivir & 3357 & 88.0 & 4.8 & 0.88 \\
Guadiana & 1916 & 89.9 & 6.2 & 0.70 \\
Jucar & 2581 & 79.6 & 2.4 & 0.84 \\
Segura & 1546 & 86.0 & 4.6 & 0.97 \\
\hline Spain & 22,181 & 82.3 & 2.8 & 0.94 \\
\hline
\end{tabular}

Source: Authors' own based on data given in [28].

Following the WATECO guidelines [18], the calculation of financial costs in the case of Spanish RBDs has been based on the sum of annual operating and maintenance costs, plus an estimation of the capital cost of irrigation infrastructures in annual terms (through the calculation of equivalent annual costs (EAC)). Additionally, RBDs are required to assess environmental and resource costs when making provisions for cost recovery. In this respect, the WATECO guidelines offer a definition of environmental costs and provided two methods of calculation: the "cost-based" and "benefit-based" approaches. The cost-based approach relies on determining the amount of expenditure to either maintain or restore a water body to a "good chemical and ecological status" as established by the WFD. The benefit-based approach relies on determining the economic value of natural resources. In the case of Spanish RBDs, and following the guidelines given by the Spanish Ministry of Agriculture, Fishing, and Environment, calculations of environmental costs are obtained on a cost-based approach. The methodology used by Spanish RBs to assess financial and environmental costs is analysed in detail in Section 4 , taking as example the case study of the GRB. Regarding resource costs, no assessment methods are provided by the WATECO guidelines, apart from a few definitions and concepts [20,29]. Most Spanish RBs do not assess any resource costs. 
In 2012, the estimated global cost-recovery rate of water services in agriculture was 0.62 in Spain, when both financial and environmental costs are accounted for (Table 3). This means a reduction with respect to the rate achieved in the previous planning cycle, due mainly to high investment in irrigation modernisation and irrigation efficiency enhancement over the last decade which has been financially supported by regional and national governments [30]. Moreover, the substitution of groundwater exploitation by surface or external resources (e.g., desalinization) is also subsidised in most RBs (such as the Segura RB), and therefore the CRP cannot be adequately applied [31]. Table 3 shows the estimated CR rates upon data on estimated costs (both financial and environmental) and revenues of water services in the agricultural sector for selected RBDs in Mediterranean Spain. No resource costs are considered in the CR assessment. In the case of Spain as a whole, environmental costs represent $20 \%$ of total costs, thereby reducing the CR rate from 0.78 to 0.62 when these costs are accounted for. In terms of each RBD, the case of the GRB shows CR rates above the Spanish average. The Segura $\mathrm{RBD}$ registers the lowest rates, due mainly to the high environmental costs associated to irrigated agriculture in that particular basin, which registers serious problems involving ecological deterioration in surface water and groundwater pollution [32].

Table 3. Financial and environmental costs, revenues, and cost-recovery rates in agriculture in Spanish Mediterranean RBDs.

\begin{tabular}{cccccc}
\hline RBD & Financial Costs & Environmental Costs & Revenues & CR Rate & CR Rate $^{\mathbf{2}}$ \\
\hline Ebro & 773.5 & 100.8 & 630.4 & 0.82 & 0.72 \\
Guadalquivir & 338.2 & 55.5 & 259.1 & 0.76 & 0.66 \\
Guadiana & 163.5 & 55.0 & 130.9 & 0.80 & 0.60 \\
Jucar & 490.2 & 56.4 & 399.1 & 0.81 & 0.73 \\
Segura & 220.2 & 141.7 & 164.3 & 0.75 & 0.45 \\
\hline Spain & 2950.1 & 760 & 2300.2 & 0.78 & 0.62 \\
\hline
\end{tabular}

Note: Costs and revenues measured in millions of euros (year 2012). ${ }^{1}$ Only financial costs. ${ }^{2}$ Financial and environmental costs. Source: Authors' own based on [17].

\section{Description of the Case-Study}

The Guadalquivir River is the longest river in southern Spain, as $650 \mathrm{~km}$ in length, with a total combined length including both the river and its tributaries of around 10,700 km. It has a basin area of over $57,527 \mathrm{~km}^{2}$, a population of 4.1 million inhabitants, and annual renewable resources estimated at $7.1 \times 10^{9} \mathrm{~m}^{3}$ for surface waters and $2.6 \times 10^{9} \mathrm{~m}^{3}$ for groundwater, making it the most important river basin in southern Spain. The basin area is made up of forests (49.1\%), agricultural land $(47.2 \%)$, urban areas $(1.9 \%)$, and wetlands (1.8\%). It has a Mediterranean climate with an average rainfall of $573 \mathrm{~mm}$, occasional periods of prolonged drought, and an average annual temperature of $16.8^{\circ} \mathrm{C}$. The current reservoir capacity in the GRB is $8560 \mathrm{hm}^{3}$ and the average water use in the basin amounts to approximately $3800 \mathrm{hm}^{3}$ per year [17], of which about $3400 \mathrm{hm}^{3}$ is used to meet the demands of irrigated agriculture (which represents $88 \%$ of the total water demand in the basin). Water rights are associated to irrigated land ownership, whereby agricultural water use (together with the rest of the economic uses, such as industry and energy) is granted a lower level of priority than domestic uses. Agricultural water use basically represents that of irrigation, as water use for livestock production is around $19 \mathrm{hm}^{3}$ (a mere $0.01 \%$ of the total use of agricultural water in the basin). Therefore, in subsequent sections, the terms agricultural sector and irrigation sector are used indistinctively.

Currently, the GRB is characterised by a state of closure, where all available water resources are allocated to increasingly high levels of competing demands and the supply capacity has reached its maximum [30]. In fact, no further conversions of rain-fed areas to irrigation are permitted (apart from those with special administrative authorisation). Except for groundwater resources, water is highly regulated by a total of 65 dams and an inter-basin transfer facility (Negratín-Almanzora) to export water from the GRB to the Mediterranean Andalusian River Basin for irrigation purposes on the basis of water trading [33]. 
The specific case study of the GRB is particularly relevant within the Spanish context, as it contains $23 \%$ of Spain's total irrigated land [17]. The competitiveness of its irrigated agriculture, which is based on high-value crops (such as citrus and olive trees), explains the remarkable expansion in irrigated areas and modernisation of irrigation systems in recent decades, to the point where there are now approximately 852,000 hectares of irrigated land. This context makes the GRB a very interesting case study for the analysis of the application of the CRP regarding water services related to the agricultural sector in the Mediterranean context.

Table 4 summarises the main instruments for cost recovery of water services in the GRB. Up-stream services are managed by the River Basin Authority (RBA), which is in charge of providing water to down-stream services (such as irrigation districts). For these services, the RBA applies abstraction charges designed to finance operational and maintenance costs, as well as investment amortization costs. Down-stream water services in the agricultural sector are commonly managed by irrigation districts or irrigation water user associations (IWUAs), which provide water to all their associated farmers at a fixed (per hectare) or volumetric (per cubic metre) price (Table 4). Most IWUAs have already implemented volumetric metering, but there are still IWUAs that use fixed charges per hectare. These charges cover all costs of these IWUAs, including investment and operating costs. They also collect farmers' levies charged by the RBA for up-stream services and transfer the revenue to the RBA. Conversely, the use of groundwater by farmers generally implies no charge per water use, apart from the administrative licensing cost (in legal abstractions). One exemption is the case of the Fuencaliente aquifer (within the GRB district), where abstraction charges to groundwater users are applied [34]. Nevertheless, illegal groundwater abstraction is widespread in the GRB and is estimated as being at $1305 \mathrm{hm}^{3}$ per year (90\% of which is used for irrigation purposes). Finally, reused (or recycled) water represents only $15.4 \mathrm{hm}^{3}$ ( $0.5 \%$ of total agricultural water use) and these costs are normally recovered by urban water charges. Total revenues in water services related to irrigated agriculture amount up to 259 million euros (Table 3).

Table 4. Main CR instruments in GRB (2012).

\begin{tabular}{|c|c|c|c|}
\hline \multicolumn{2}{|c|}{ Water Services } & Instruments & Prices \\
\hline Up-stream services & Surface regulated waters & $\begin{array}{l}\text { Abstraction charge } \\
\text { "Canon de regulación and } \\
\text { Tarifa de utilización del agua" }\end{array}$ & $0.034 € / \mathrm{m}^{3}$ \\
\hline \multirow{3}{*}{ Down-stream services } & Surface regulated waters & $\begin{array}{c}\text { Irrigation charge } \\
\text { (charged by IWUAs) }\end{array}$ & $\begin{array}{l}0.064 € / \mathrm{m}^{3} \\
262.9 € / \mathrm{ha}\end{array}$ \\
\hline & $\begin{array}{l}\text { Non-regulated and } \\
\text { groundwaters (GW) }\end{array}$ & \multicolumn{2}{|c|}{$\begin{array}{l}\text { No legal charges for water use. } \\
\text { Operating costs supported by users } \\
\left(\text { Average cost } 0.15 € / \mathrm{m}^{3}\right)\end{array}$} \\
\hline & Recycled & Urban water charges & $0.24 € / \mathrm{m}^{3}$ \\
\hline
\end{tabular}

\section{Assessment of the Application of the CRP in the Guadalquivir River Basin}

This section aims to offer a detailed assessment of financial, environmental and resource costs associated to the irrigation sector in the GRB case study. Section 4.1 offers an assessment of the $\mathrm{CR}$ rates regarding financial and environmental costs of water services used by the irrigation sector. Section 4.2 applies a simple method to estimate the resource cost in the GRB. Finally, CR rates are assessed following the inclusion of the estimation of resource cost.

\subsection{Financial and Environmental Costs}

Financial costs associated to the water infrastructures used by the irrigation sector are normally calculated by means of the monetary valuation of capital costs plus the operational and management $(\mathrm{O} \& M)$ costs of that infrastructure. Those costs are converted into an EAC (Equation (1)). Thus, capital costs are converted to current values (values of 2012 in the second cycle RBMPs) and the EAC is 
estimated based on the expected life-time of the infrastructure $(n)$ and an annual discount rate of $r=0.75 \%$ (centrally fixed by the Spanish Ministry of Agriculture, Fishing, and Environment and obtained upon historical depreciation criteria). This is the method used by the Guadalquivir RBA [17], where total EAC of water services (up- and down-streams) used by the irrigation sector is obtained upon de sum of the $\mathrm{k}$ individual $E A C_{\mathrm{i}}$ calculated for every water service facility (or infrastructure).

$$
\text { Global EAC }=\sum_{i=1}^{k} E A C_{i}=\sum_{i=1}^{k}\left[\text { Capital cost }_{i}\left[\frac{(1+r)^{n} \times r}{(1+r)^{n}-1}\right]+\text { O\&M cost } t_{i}\right]
$$

Nevertheless, it is worth noting that the use of historical depreciation criteria to calculate capital costs (as part of financial costs) provides no guarantee of the recovery of capital replacement costs. Therefore, by the time infrastructure elements become obsolete or fully depreciated, the flow of paid charges during the life-time would never be enough to build new elements [7]. Although Spain has been granted permission by the EC to use historical depreciation values for the determination of CR rates, the issue of replacement costs has yet to be considered by the WFD.

Regarding the evaluation of environmental costs, there exist different methodologies, although only a few of them have been fully applied at a river basin scale. Some examples can be found in the existing literature $[35,36]$. Nevertheless, environmental cost valuation first requires clarification of which environmental effects are to be considered and of the measures necessary to internalise them [6]. Moreover, the internalisation of these external costs (e.g., deterioration of water quality by agrochemical diffuse pollution) would imply identifying a compensation from the causing agent (e.g., as a result of production or consumption decisions) to the affected agent (e.g., the society as a whole) [37]. In the specific case of the GRB (and the rest of the Spanish RBDs), the existing legal framework establishes that the valuation of environmental costs should focus on the economic valuation of the damages caused, which is simplified by the cost of those measures to prevent/reduce said damages. These measures are listed and evaluated in the PoMs (as accompanying report of the RBMP). Thus, a cost-based approach is applied. This approach establishes that, while environmental damage persist, environmental costs must be accounted for. Once damages disappear, then the environmental costs convert into financial costs (all measured in EAC terms). At this point, it is worth noting that this approach uses environmental protection costs as a lower-bound proxy for the costs of external environmental damage, since benefits would generally compensate for the costs of the measures related to environmental improvement [38]. Although this assumption is consistent in a suboptimal state, where the cost of pollution abatement (protection cost) is always lower than the benefit of reducing the damage (cost of damage), the cost-based approach is easier to implement by decision-makers due to its better data availability. Theoretically, the optimum situation would be reached when these two costs become equal.

Therefore, environmental cost associated to the irrigation sector in the GRB is estimated upon the costs related to the necessary measures (as listed in the PoMs) to prevent or reduce the environmental damages caused by irrigation (e.g., diffuse agrochemical pollution of surface and groundwater bodies). Capital and O\&M costs associated to this measure are used to estimate EACs, following a similar method to that used in the case of financial costs (Equation (1)). Table 5 summarises the global financial and environmental EACs related to agricultural water services in the GRB for 2012, as well as the estimated CR rates. In the case of the GRB (as well as in Spain, as a whole), there are no policy instruments specifically designed to recover those environmental costs directly related to agricultural activities, such as water pollution taxes (e.g., on pesticides or fertilisers as introduced by Belgium, Denmark and France) or water abstraction taxes designed to recover (at least partially) environmental costs (as introduced in France and Portugal) [7]. Due to this fact, CR rates in all water services in agriculture remain far from showing an adequate recovery of costs, regarding both financial and environmental, thus being only partially financed by the revenues obtained from the instruments summarized in Table 4. 
Table 5. Estimations of financial (F) and environmental (E) costs (total EACs) by water service and CR rates.

\begin{tabular}{ccccc}
\hline \multicolumn{2}{c}{ Water Services } & $\begin{array}{c}\text { Financial Costs (F) } \\
\text { (Million } \boldsymbol{€})\end{array}$ & $\begin{array}{c}\text { Environmental Costs (E) } \\
\text { (Million } \boldsymbol{€} \text { ) }\end{array}$ & CR Rate \\
\hline Up-Stream Services & Regulated & 47.5 & 7 & 0.60 \\
\hline \multirow{2}{*}{$\begin{array}{c}\text { Down-Stream } \\
\text { Services }\end{array}$} & Regulated & 90.7 & 40.9 & 0.69 \\
\cline { 2 - 5 } & Non-regulated and GW & 196.4 & 3.7 & 0.66 \\
\cline { 2 - 5 } & Recycled & 4.0 & 3.9 & 0.48 \\
\hline Global & & 338.4 & 55.5 & $0.66^{2}$ \\
\hline
\end{tabular}

Note: Estimates for year 2012. ${ }^{1}$ Including financial and environmental costs. ${ }^{2}$ Weighted by served water. Source: Authors' own based on [17].

\subsection{Assessment of Resource Cost and Cost Recovery}

In the case of Spanish RBDs, the valuation of resource costs is either proxied by simple methods or simply not considered. This subsection aims to offer a simple evaluation of resource costs in the case of the GRB. Valuation of resource scarcity costs in monetary terms usually present both methodological and empirical difficulties [7]. Additionally, the literature has mostly focused on the estimation of environmental values related to water quality by overseeing quantitative aspects, such as those related to resource (or opportunity) costs [39]. Though resource costs have generally not been analysed in Spanish RBMPs, Art. 9 of the WFD clearly specifies the need for its estimation and recovery through the use of alternative economic instruments, so that an efficient use (and allocation) of water resources can be assured. Nevertheless, in river basins such as the GRB, characterised by a closure status with total available water resources allocated and increasing pressure from competition between various water users (including irrigated agriculture), the assessment of resource (or opportunity) costs of alternative resource allocations seem especially necessary. Although the majority of Spanish RBMPs have considered resource costs to be part of the environmental costs or have assumed them to be zero [5], the last GRBMP attempts to offer a calculation around 2.2 million euros, which clearly underestimates the real value, especially in a closed RB with increasing competition among alternative users. In this respect, this study aimed to offer a simple alternative valuation of the resource cost of water services in agriculture based on existing market prices of the resource, which may serve to offer RBAs more realistic estimations of the resource costs associated to irrigation water uses.

Resource costs are associated with the economic value of the opportunities forgone when allocating the resource to a given use [28], and thus they can be approached based on alternative water valuation methods (e.g., residual value) or market prices, which should be netted of the costs incurred by abstracting and moving the water from one use to its final destiny [7]. Despite methodological shortcomings, various methods can be used in our specific case study, as there is available information regarding water transfer prices within the GRB and RBs nearby in Spain [40] [41], estimations of irrigation water values following the residual value method [42], and regarding apparent productivity values [30]. Specifically, the proposed method aims to offer an estimation of the resource cost based on transfer prices.

Although the ranking of priorities established in the GRB (domestic vs. economic uses, including irrigation) limits water trade, thereby implying that most transfer agreements have occurred within the agricultural sector, other economic sectors (e.g., hydropower and industry) could also participate as trading agents [33]. Table 6 summarises the latest evidence regarding agreed water prices in water transfers or sales (both intra- and inter-basin) and water banks in Spain for irrigation purposes. Most water exchanges of this type took place during the drought period of 2005-2008, and hence prices have been brought up-to-date to 2012 (fourth column in Table 6). The average price is $0.21 € / \mathrm{m}^{3}$, which is close to the updated price of the last inter-basin water transfer between the GRB and the Mediterranean Andalusian RB in 2008 with a sale price of $0.18 € / \mathrm{m}^{3}$ (apart from the transfer costs of $0.13 € / \mathrm{m}^{3}$ for the use of the Negratín-Almanzora transfer facility). 
Table 6. Evidence on prices of water sales and water banks in Spain.

\begin{tabular}{cccc}
\hline Intra-Basin Water Transfers & Year & Price $\left(\mathbf{\epsilon} / \mathbf{m}^{\mathbf{3}}\right)$ & Price (2012) \\
\hline Mediterranean Andalusian RB & 2007 & 0.15 & 0.16 \\
Segura RB & 2012 & 0.22 & 0.22 \\
GRB to Mediterranean Andalusian RB & $2006-2008$ & 0.18 & 0.20 \\
Tagus RB to Segura RB & 2008 & 0.22 & 0.24 \\
Water banks & & & \\
Júcar RB & 2008 & 0.25 & 0.27 \\
Segura RB & 2008 & 0.17 & 0.18 \\
Average & & & 0.21 \\
\hline
\end{tabular}

Source: Authors' own based on [40,41].

In recent years, inter-basin transfers for irrigation purposes from the GRB to the Mediterranean Andalusia RB through the Negratín-Almanzora transfer facility have commonly taken place, and the administrative transfer cost has remained mostly unchanged: currently set at $0.13 € / \mathrm{m}^{3}$ (this price is set to cover all financial costs of the transfer facility). These transfers are administratively limited to an annual maximum of $50 \mathrm{Hm}^{3}$ for the irrigation of approximately 24,000 hectares, and therefore permitted transfers have varied depending on the hydrological reserves of the GRB, whereby no transfers are allowed when water reserves fall below 30\% of the GRB storage capacity. Although during drought periods transfers have not been permitted, users have been able to negotiate water sales under special authorisation of the RBA. In December 2006, Aguas de Almanzora (a consortium of 18 irrigator associations located in the Mediterranean Andalusian RB) bought rice farms in downstream GRB to acquire water-use rights and transfer that water to irrigate horticulture crops and citrus trees in the Mediterranean Andalusian RB [40]. Since buyer and seller were the same, no sale price was set (except for the transfer costs of $0.13 € / \mathrm{m}^{3}$ ). Nevertheless, the purchase price for the rice farms $\left(24,000 € /\right.$ ha) implied a water cost equivalent to $0.18 € / \mathrm{m}^{3}$ [43]. This cost is similar to additional water purchases carried out by Aguas de Almanzora, who in 2007 and 2008 bought water from various IWUAs in the GRB. In those operations, the sale price was set at approximately $0.18 € / \mathrm{m}^{3}$ (similar to that paid in 2006) [40]. This price, updated to 2012, will be used as a trading value to estimate the resource cost in the GRB $\left(0.20 € / \mathrm{m}^{3}\right)$. The proposed method can therefore be summarised in the following postulations:

(a) Water used by agriculture in down-stream services is used for the estimate. By means of omitting the simultaneous inclusion of up-stream and down-stream services, double accounting of the costs is avoided. Additionally, the use of down-stream services enables groundwater use by agriculture to be accounted for in the overall estimation.

(b) Estimation of the resource cost should be estimated considering the specific characteristics of the GRB, thereby taking as reference values those set by trading prices agreed in the context of the GRB. Specifically, the sale price of the latest inter-basin transfer from the GRB for irrigation purposes set at $0.20 € / \mathrm{m}^{3}$ (in prices of 2012) has been considered.

(c) A proxy of the resource cost can be obtained upon the difference (or additional cost) between current cost paid by the irrigation sector and the price that this sector would be willing to pay in the case of resource scarcity (around $0.20 € / \mathrm{m}^{3}$ ) multiplied by the served water in each down-stream water service (Table 7).

Based on these postulations, a simple assessment of the resource cost in the GRB is offered in Table 7. Total resource costs would be around 269 million euros, where surface water use for irrigation would account for approximately $77 \%$ of total cost. In the case of the use of recycled water, no resource cost would be applicable. Full cost recovery of resource cost would mean an increase of around $0.08 € / \mathrm{m}^{3}$ (269 million $\left.€ / 3264 \mathrm{hm}^{3}\right)$, well above previous estimations although it would depend on the down-stream service considered [39,43]. In this regard, it is worth mentioning that this estimation attempts to serve as only a proxy of the resource cost in the GRB regarding agricultural water use, and 
where the method used is just one of the multiple methods that can be used. Additionally, full cost recovery of resource cost should be carefully considered since it would be controversial to transfer it directly to irrigation tariffs, either for effectiveness [44] or social [45] reasons. This point will be further discussed in the subsequent section.

Table 7. Estimation of resource cost in the GRB.

\begin{tabular}{|c|c|c|c|c|}
\hline Down-Stream & $\begin{array}{l}\text { Current Cost } \\
\left(€ / \mathrm{m}^{3}\right)\end{array}$ & $\begin{array}{l}\text { Additional Cost } \\
\qquad\left(€ / \mathrm{m}^{3}\right)^{1}\end{array}$ & $\begin{array}{l}\text { Served Water } \\
\left(\mathrm{hm}^{3}\right)^{2}\end{array}$ & $\begin{array}{l}\text { Resource Cost } \\
(\text { Million } €)^{1 \times 2}\end{array}$ \\
\hline Regulated & 0.098 & 0.102 & 2061 & 210 \\
\hline Non-regulated and GW & 0.15 & 0.05 & 1188 & 59 \\
\hline Recycled & 0.24 & n.a. & 15.4 & n.a. \\
\hline Total & - & - & 3264 & 269 \\
\hline
\end{tabular}

Note: Estimates for 2012. Source: Authors' own. ${ }^{1}$ : Additional Cost; ${ }^{2}$ : Served Water $\left(\mathrm{hm}^{3}\right)$.

Once the resource cost has been estimated, global cost-recovery rates (including financial, environmental and resource costs) for irrigated agriculture in the GRB can be obtained (Table 8). Results show that CR rates fall below 0.5 if resource cost is considered. As discussed further in the subsequent section, these results may carry major policy and social implications. Nevertheless, the application of the CRP, as defined by the WFD, does not mean the achievement of full cost recovery in all water services and sectors, since exceptions can be widely used by MS based on sufficient justification. For this reason, complete and adequate assessments of all costs related to the provision of water services, including environmental and resource costs, should be addressed in RBMPs regardless of the $\mathrm{CR}$ rate achieved, the application of sufficient recovery cost instruments, and/or the existence of justified exceptions. Additionally, cost transparency and societal knowledge regarding the degree of agricultural subsidisation in the use of water resources would be better addressed in RBMPs, in accordance with the WFD policy principles.

Table 8. Global cost-recovery rate by water service.

\begin{tabular}{ccc}
\hline \multicolumn{2}{c}{ Water Services } & CR Rate \\
\hline Up-stream services & Regulated & 0.60 \\
\hline \multirow{2}{*}{ Down-stream services } & Regulated & 0.27 \\
\cline { 2 - 3 } & Non-regulated and GW & 0.51 \\
\cline { 2 - 3 } & Recycled & 0.48 \\
\hline Global & & $0.44^{1}$ \\
\hline
\end{tabular}

Note: Estimates for 2012. ${ }^{1}$ Weighted by served water. Source: Authors' own.

\section{Discussion and Policy Implications}

The value of water to society clearly goes beyond its simple valuation as a productive input (e.g., in irrigated agriculture) [46]. Nevertheless, a more complete knowledge of all costs related to the agricultural use of water resources doubtless brings more transparency to society and for policy analysis [7]. Although not all costs related to the provision of water services can be recovered, as for instance those related to flood and drought prevention cannot be assigned to a specific economic use [33], the application of the principle of cost recovery in all water services requires the assessment of all costs addressed by the WFD, including financial, environmental and resource costs [2]. The CRP is accepted as a primary principle in EU water policy and, based on the concept of water services, its application is directly related to the achievement of the environmental objectives set by the WFD [23]. In this sense, the selection of measures in RBMPs (and PoMs) to restore the "good status" in all bodies of water provide important information for the design of cost-recovery instruments (e.g., water 
pricing, eco-taxes, etc.). However, across the EU, very few RBMPs contain a plausible description of all economic costs (financial, environmental and resource costs) related to agricultural water use [22]. In this respect, the European Commission has asserted that there has been a lack of determined action in most MS to address the costs of water services used by the agricultural sector, since those in charge of the design and implementation of RBMPs (e.g., RBAs and regional governments) do not have full legislative power to enforce implementation of the CRP [2,47]. Furthermore, the lack of political will in central and/or regional governments to dismantle the traditional subsidy-based agricultural systems is usually caused by social considerations $[5,8]$. Specifically, the reluctance to increase water irrigation charges (and thus, CR rates) in Spain has normally been defended on two bases: (a) the existence of public services provided by agriculture in terms of food security and environmental benefits; and (b) a sector competitiveness issue, since farmers' costs would otherwise dramatically increase.

With respect to the first argument, the application of the CRP to agriculture does not necessarily imply the abolition of subsidies received by the agricultural sector as provider of public goods and services, such as maintenance of rural landscapes and preservation of habitats and ecosystems in rural environments [48]. An ideal policy mix would utilize separate instruments to compensate agriculture for the benefits and to penalize for the drawbacks [46], thus balancing between an adequate cost recovery based on fiscal charges (e.g., water charges and pollution taxes) and compensation for ecosystem services provided by agriculture [7]. Furthermore, differences among different types of agriculture (e.g., traditional vs. commercial) need to be considered in this balance. In this context, the sufficient contribution of agriculture to cover all costs associated to its use of water resources would no longer remain a controversial issue, as it would be perfectly acceptable for efficiency and equity reasons.

Nevertheless, various studies have established a clear connection between agricultural subsidies and the increase of irrigated agriculture, which increases the pressures on water resources $[45,49,50]$. Spanish irrigation modernisation programs have generally encouraged changes in the crop-mix towards high-value crops (citrus, horticulture, etc.), even though intensive irrigated agriculture constitutes the main cause of degradation (both qualitative and quantitative) of surface and groundwaters [10,31]. Public subsidies for the modernisation of irrigation schemes have generally implied a reduction of the cost recovery rates [51]. Additionally, the EU Common Agricultural Policy (CAP) supported the development of agriculture of a more profitable (and input-intensive) nature until its reform in 2013, which enlarged the cross-compliance system between the receipt of subsidies and the respect for a set of environmental goals (including water-quality issues) [52]. Nevertheless, and despite the advances in last decade, the coordination of the CAP and water environmental policies still needs to be further improved to achieve a more sustainable use of water resources $[20,53]$. This might also require a reformulation of the CRP to account for external environmental costs of irrigated agriculture, for the implementation of innovative recovery cost instruments to finance the foreseen environmental measures in the PoMs [54], and for the revision of exceptions and greening standards set in the CAP with respect to agricultural water use [14].

Regarding sector competitiveness, it seems clear that higher water prices will inevitably increase costs at farm level. In this respect, some studies (e.g., [7]) argue that the share of water in total farm costs is not highly significant (e.g., in average terms, water cost represents less than $2 \%$ of cultivation costs in Spain) and that innovative management and technology will enable farmers to generate greater value per irrigation water unit. In contrast, other studies have shown that higher irrigation water charges would result in negative effects for low-productive farmers and those with no power to translate costs to crop prices [55-57]. Thus, traditional (and less-profitable) agricultural exploitations would need special measures to guarantee their economic viability (e.g., through financial compensation for the provision of ecosystem services to society). Conversely to the household sector, where certain studies have defined threshold cost (or water-poverty) levels [58,59], no defined criteria exist for the assessment of cost-increase affordability among agricultural water users. Only the OECD [7] has proposed the concept of "sustainable cost recovery" for the agricultural sector, based on a limited financial 
sustainability in the provision of water services (and therefore fails to consider environmental and resource costs). Along these lines, [60] argue that irrigated olive farmers in the GRB would be willing to pay higher water prices based on an increase in reliability of irrigation supply, up to $0.07 € / \mathrm{m}^{3}$ (which is close to our estimated increase for resource cost recovery). Other studies (e.g., [7,61,62]) argue that pricing policies may have no significant impact on overall income distribution for agriculture, although they may negatively affect certain groups, such as small and low-productive farmers. In this respect, several studies argue that equity and distributional effects could be minimized through water-pricing schemes with increasing block tariffs, together with rural development policies aimed at aiding specific low-value and subsistence farming $[3,63,64]$. Additionally, those new financial resources could be invested in measures for the improvement of supply reliability, irrigation modernisation programs, renewal of irrigation infrastructure, and rural development measures (e.g., financially reinforcing the CAP second pillar), thereby enhancing the willingness to pay among benefitting farmers.

In this respect, several EU countries, such as France and the Netherlands, have created special levies (or eco-charges) on irrigation water use, both for surface and groundwater abstraction, in an attempt to internalise environmental and resource costs [7]. In general, the level of cost recovery achieved by these levies has been low due to its low rates (around $0.003 € / \mathrm{m}^{3}$ in France), which has led to its abolishment in the case of the Netherlands. Portugal has recently introduced a water abstraction charge (of approximately $0.004 € / \mathrm{m}^{3}$ ), designed to guarantee certain contribution of the irrigation sector to internalise part of the resource cost, and not with the objective of a full cost recovery. Other countries, such as Spain, are debating whether to implement this type of eco-tax. In this respect, [56] argued that the introduction of an eco-tax (of around $0.02 € / \mathrm{m}^{3}$ ) in Spain would help to achieve both a higher contribution of the irrigation sector to cover water service costs and the resources needed to adequately fulfil the WFD environmental objectives. Nevertheless, this study recommends that this increase in irrigation charges be followed by measures aimed at avoiding negative effects on impoverished rural areas. A simple calculation in the case of the GRB based on the estimated environmental costs (55.5 Million Euros in Table 5) and water served for irrigation purposes $\left(3264 \mathrm{Hm}^{3}\right.$ in Table 7 ) yields an average environmental cost of $0.02 € / \mathrm{m}^{3}$ (similar to that proposed in [56]). In our opinion, this would help to internalise the environmental costs associated to the irrigation sector. Again, it is worth mentioning that the application of exceptions is always possible, and depends on the social, environmental, and economic effects of the cost-recovery instrument used, as well as on the geographic and climatic conditions of the specific area or region. However, any exemption needs to be sufficiently justified and has to be shown not to detract from the environmental objectives of the WFD [5].

The question therefore remains: is this exceptional treatment, regarding the application of the CRP to irrigated agriculture, sustainable in the future? Many policy makers still believe so for the aforementioned reasons and for the way that subsidies are seen as a way to guarantee fairness and efficiency in Spanish and European agricultures [14,65]. Nevertheless, Spanish society is becoming more reluctant to subsidise economic sectors that impose external costs to current and future generations. Additionally, an increase in the internalisation of water costs by the irrigation sector (albeit partially) does not run contrary to the establishment of compensations for agriculture environmental services and rural development, but against indiscriminate cost subsidising and the absolute lack of the internalisation of environmental and resource cost. European authorities are insisting on the need for pricing measures of a more transparent and incentivising nature in the irrigation sector, and a move towards similar treatment as received by other economic sectors [27,64]. Moreover, a fair and incentivised pricing system may provide the resources necessary to finance the measures aimed at achieving a "good" status in all those water bodies affected by agricultural pressure, without endangering the provision of agricultural and rural benefits to society.

\section{Conclusions}

The CRP is considered by the EU water policy to be a substantial requirement for economic efficiency, transparency, fairness, and sustainability in the use of water resources. On the one hand, 
this paper has analysed the application of the CRP to the agricultural irrigation sector, as a water service beneficiary, in Spain through the assessment of the GRB case study. Our results indicate that, although financial and environmental costs are assessed in the current RBMP, no formal assessment of the resource (or scarcity) costs is carried out, as remains the case for all Spanish RBDs. Furthermore, the evaluation of financial and environmental costs carried out in the current GRBMP register several shortcomings, which have been highlighted in this study. Estimated cost recovery rates are generally low in all water services used by the irrigation sector. Further efforts should therefore be made to adequately estimate the costs of water services used by the irrigation sector so a higher economic efficiency, transparency, fairness, and sustainability in the use of water resources can be achieved.

Additionally, this study offers a much-needed discussion about the agricultural "exceptionalism" phenomenon regarding the application of the CRP to water services. This "exceptionalism" applies to other primary principles of EU water and environmental policy, such as the Polluter Pays Principle (which lies beyond the scope of this paper). The main arguments against full application of the CRP to irrigated agriculture are based on the justification through the existence of public services provided by agriculture and the sector's competitiveness. As discussed in this paper, these two arguments are not necessarily in opposition to the application of the CRP.

Finally, an assessment of financial, environmental and resource costs related to the irrigation sector is necessary to determine the appropriate cost-recovery measures and the exemptions deemed acceptable by society. The current process of the third-cycle RBMPs represents an ideal means to gain transparency, equity, and efficiency in the way the irrigation sector uses water resources; all this when EU water and agricultural policies are also under review in order to guarantee the most sustainable development of agriculture on using such a strategic natural resource.

Funding: This research received funding support from the Department of Economic Analysis of University of Seville (Spain) and from the research contract with grant number (3273/0920).

Acknowledgments: Author acknowledges the valuable comments received by Erik Gawel and Bernd Klauer from the Helmholtz Centre for Environmental Research (Leipzig, Germany). Statements and opinions expressed in this manuscript exclusively reflect the view of the author.

Conflicts of Interest: The author declares no conflict of interest. The funders had no role in the design of the study; in the collection, analyses, or interpretation of data; in the writing of the manuscript, and in the decision to publish the results.

\section{References}

1. FAO. Irrigation Water Requirement and Water Withdrawal by Country; Food and Agriculture Organization: Rome, Italy, 2012.

2. EC. The Water Framework Directive and the Floods Directive: Actions towards the 'Good Status' of EU Water and to Reduce Flood Risks; Communication from the Commission to the European Parliament and the Council, COM (2015) 120 Final; EC: Brussels, Belgium, 2015.

3. EEA. Assessment of Cost Recovery through Water Pricing; EEA Technical Report 16/2013; Publications Office of the European Union: Luxembourg, 2013.

4. Unnerstall, H. The Principle of Full Cost Recovery in the EU-Water Framework Directive-Genesis and Content. J. Environ. Law 2007, 19, 29-42. [CrossRef]

5. Gómez-Limón, J.A.; Martin-Ortega, J. The economic analysis in the implementation of the Water Framework Directive in Spain. Int. J. River Basin Manag. 2013, 11, 301-310. [CrossRef]

6. Reese, M. Cost recovery and water pricing in water services and water uses in Germany. J. Eur. Environ. Plan. Law 2013, 10, 355-377. [CrossRef]

7. OECD. Sustainable Management of Water Resources in Agriculture; OECD Publishing: Paris, France, 2010.

8. Gawel, E. Article 9 of the EU Water Framework Directive. J. Eur. Environ. Plan. Law 2014, 11, $249-271$. [CrossRef]

9. Ahodo, K.; Svatonova, T. The use of economic instruments in environmental policies to mitigate diffuse pollution from agriculture. Agric. Econ. 2014, 60, 74-81. 
10. Esteban, E.; Albiac, J. Assessment of Nonpoint Pollution Instruments: The Case of Spanish Agriculture. Int. J. Water Resour. Dev. 2012, 28, 73-88. [CrossRef]

11. Alcon, F.; Martin-Ortega, J.; Berbel, J.; de Miguel, M.D. Environmental benefits of reclaimed water: an economic assessment in the context of the water framework directive. Water Policy 2012, 14, 148. [CrossRef]

12. EU. Directive 2000/60/EC of the European Parliament and of the Council establishing a framework for the Community Action in the Field of Water Policy; European Union: Brussels, Belgium, 2000.

13. Daugbjerg, C.; Feindt, P.H. Post-exceptionalism in public policy: Transforming good and agricultural policy. J. Eur. Public Policy 2017, 24, 1565-1584. [CrossRef]

14. Greer, A. Post-exceptional politics in agriculture: An examination of the 2013 CAP reform. J. Eur. Public Policy 2017, 24, 1585-1603. [CrossRef]

15. Pollans, M.J. Drinking Water Protection and Agricultural Exceptionalism; Pace Law Faculty Publications: New York, NY, USA, 2016.

16. Boeuf, B.; Fritsch, O.; Martin-Ortega, J. Undermining European Environmental Policy goals? The EU Water Framework Directive and the politics of exemptions. Water 2016, 8, 388. [CrossRef]

17. CHG. Plan Hidrológico de la Demarcación del Guadalquivir 2015-2021; R. D. 1/2016; Confederación Hidrográfica del Guadalquivir: Sevilla, Spain, 2016.

18. EC. Common Implementation Strategy for the Water Framework Directive (2000/60/EC); Guidance Document No. 1: Economics and the Environment: The Implementation Challenge of the Water Framework Directive (WATECO); European Commission: Brussels, Belgium, 2003.

19. Maia, R. The WFD implementation in the European Member States. Water Resour. Manag. 2017, 31, $3043-3060$. [CrossRef]

20. Berbel, J.; Expósito, A. Economic challenges for the EU Water Framework Directive reform and implementation. Eur. Plan. Stud. 2018, 26, 20-34. [CrossRef]

21. Boyle, S. The case for regulation of agricultural water pollution. Environ. Lett. Rev. 2014, 16, 4-20. [CrossRef]

22. EEB. 10 Years of the Water Framework Directive: A Toothless Tiger; A Snapshot Assessment of EU Environmental Ambitions; European Environment Bureau: Brussels, Belgium, 2010.

23. EC. The Role of Water Pricing and Water Allocation in Agriculture in Delivering Sustainable Water Use in Europe; Final Report; European Commission: Brussels, Belgium, 2013.

24. Giannakis, E.; Bruggeman, A.; Djuma, H.; Zozyra, J.; Hammer, J. Water pricing and irrigation across Europe; opportunities and constraints for adopting irrigation scheduling decision support systems. Water Sci. Technol. 2016, 16, 245-252. [CrossRef]

25. EC. Report on the Progress in Implementation of the Water Framework Directive. Programmes of Measures; Commission Staff Working Document; EC: Brussels, Belgium, 2015.

26. Cornish, G.; Bosworth, B.; Perry, G.; Burke, J. Water Charging in Irrigated Agriculture. An Analysis of International Experience; FAO Water Reports 28; FAO: Rome, Italy, 2004.

27. European Commission. A Blueprint to Safeguard Europe's Water Resources; Communication from the commission to the European Parliament, The Council, The European Economic and Social Committee and The Committee of the Regions. COM (2012) 673 Final; EC: Brussels, Belgium, 2012.

28. MAPAMA. Avances de los Análisis Económicos en los Planes de Demarcación y Recomendaciones; Grupo de Análisis Económico del Agua, Ministerio de Agricultura, Pesca, Alimentación y medio Ambiente, Gobierno de España: Madrid, Spain, 2017.

29. EDG. Assessment of Environmental and Resource Costs under the Water Framework Directive; European Drafting Group ECO2; EDG: Brussels, Belgium, 2004.

30. Expósito, A.; Berbel, J. Agricultural irrigation water use in a closed basin and the impacts on water productivity: The case of the Guadalquivir river basin (Southern Spain). Water 2017, 9, 136. [CrossRef]

31. Garrido, A.; Martínez-Santos, P.; Llamas, M.R. Groundwater irrigation and its implications for water policy in semiarid countries. Hydrogeol. J. 2006, 14, 340. [CrossRef]

32. Grindlay, A.L.; Zamorano, M.; Rodríguez, M.I.; Molero, E.; Urrea, M.A. Implementation of the European Water Framework Directive: Integration of hydrological and regional planning at the Segura River Basin, southeast Spain. Land Use Policy 2011, 28, 242-256. [CrossRef]

33. Berbel, J.; Kolberg, S.; Martin-Ortega, J. Assessment of the draft hydrological basin plan of the Guadalquivir river basin (Spain). Int. J. Water Resour. Dev. 2012, 28, 43-55. [CrossRef] 
34. Berbel, J.; Expósito, A.; Borrego-Martín, M.M. Conciliation of competing uses and stakeholders rights to groundwater: An evaluation of Fuencaliente Aquifer (Spain). Int. J. Water Resour. Dev. 2018. [CrossRef]

35. Martin-Ortega, J.; Berbel, J. Using multi-criteria analysis to explore non-market monetary values of water quality changes in the context of the Water Framework Directive. Sci. Total Environ. 2010, 408, 3990-3997. [CrossRef] [PubMed]

36. Brouwer, R.; Martin-Ortega, J.; Berbel, J. Spatial heterogeneity in choice experiments. Land Econ. 2010, 86, 552-568. [CrossRef]

37. Perman, D.; Ma, Y.; Common, M.; Maddison, D.; McGillivray, J. Natural Resource and Environmental Economics; Pearson: Harlow, UK, 2011.

38. Martin-Ortega, J. Los beneficios ambientales de las aguas del Guadalquivir: Un análisis económico; Fundacion Publica Centro de Estudios Andaluces: Sevilla, Spain, 2010.

39. Martin-Ortega, J.; Giannoccaro, G.; Berbel, J. Environmental and resource costs under water scarcity conditions: An estimation in the context of the European Water Framework Directive. Water Resour. Manag. 2011, 25, 1615-1633. [CrossRef]

40. Palomo-Hierro, S.; Gómez-Limón, J.A.; Riesgo, L. Water markets in Spain: Performance and challenges. Water 2015, 7, 652-678. [CrossRef]

41. Montilla-López, N.; Gutiérrez-Martín, C.; Gómez-Limón, J.A. Water banks: What have we learnt from the international experience? Water 2016, 8, 466. [CrossRef]

42. Berbel, J.; Mesa-Jurado, M.A.; Pistón, J.M. Value of irrigation water in Guadalquivir basin (Spain) by residual value method. Water Resour. Manag. 2011, 25, 1565-1579. [CrossRef]

43. Berbel, J.; Mesa, P. Valoración del agua de riego por el método de precios quasi-hedónicos: Aplicación al Guadalquivir. Econ. Agrar. Recur. Nat. 2011, 7, 127-144. [CrossRef]

44. Expósito, A.; Berbel, J. Why is water pricing ineffective for deficit irrigation schemes? A case study in southern Spain. Water Resour. Manag. 2017, 31, 1047-1059. [CrossRef]

45. Gómez-Limón, J.A.; Arriaza, M.; Berbel, J. Conflicting implementation of agricultural and water policies in irrigated areas in the EU. J. Agric. Econ. 2002, 53, 259-281. [CrossRef]

46. Rogers, P.; de Silva, R.; Bhatia, R. Water is an economic good: How to use prices to promote equity, efficiency, and sustainability. Water Policy 2002, 4, 1-17. [CrossRef]

47. European Commission. Accompanying Document to 'Towards Sustainable Water Management in the European Union: First Stage in the Implementation of the Water Framework Directive 2000/60/EC'; COM (2007) 128 Final; EC: Brussels, Belgium, 2007.

48. Grossman, M.T. Agriculture and the polluter pays principle: An introduction. Okla. Law Rev. 2006, 59, 1-52.

49. Arriaza, M.; Gómez Limón, J.A.; Ruiz, P. Evaluación de alternativas de desacoplamiento total de ayudas COP: El caso de la agricultura de regadío del Valle del Guadalquivir. Econ. Agrar. Recur. Nat. 2003, 6, 129-153. [CrossRef]

50. Garrido, A.; Varela-Ortega, C. Economía del Agua en la Agricultura e Integración de Políticas Sectoriales; Panel Científico técnico de seguimiento de la política de aguas, University of Seville and Ministry of the Environment: Seville, Spain, 2008.

51. García-Mollá, M.; Ortega-Reig, M.; Sanchis-Ibor, C.; Avellà-Reus, L. The effects of irrigation modernisation on the cost recovery of water in the Valencia Region (Spain). Water Sci. Technol. 2014, 14, 414-420. [CrossRef]

52. EC. Commission Delegated Regulation (EU) 640/2014 of 11 March 2014 Supplementing Regulation (EU) 1306/2013 of the European Parliament and of the Council with Regard to the Integrated Administration and Control System and Conditions for Refusal or Withdrawal of Payments and Administrative Penalties Applicable to Direct Payments, Rural Development Support and Cross Compliance; EC: Brussels, Belgium, 2014.

53. Bartolini, F.; Gallerani, V.; Raggi, M.; Viaggi, D. Connecting agri-environmental schemes and cross-compliance designs: An explanatory case study in Emilia Romana. In The Common Agricultural Policy after the Fischler Reform: National Implementations, Impact Assessment and the Agenda for Future Reforms; Sorrentino, A., Henke, R., Severini, S., Eds.; Routledge: London, UK, 2016; pp. 313-330.

54. Mohaupt, V.; Crosnier, G.; Todd, R.; Petersen, P.; Dworak, T. WFD and agriculture activity of the EU: First linkages between the CAP and the WFD at EU Level. Water Sci. Technol. 2007, 56, 163-170. [CrossRef] [PubMed]

55. Berbel, J.; Gómez-Limón, J.A. The impact of water pricing policy in Spain: An analysis of three irrigated areas. Agric. Water Manag. 2000, 43, 219-238. [CrossRef] 
56. Riesgo, L.; Gómez-Limón, J.A. Multi-criteria policy scenario analysis for public regulation of irrigated agriculture. Agric. Syst. 2006, 91, 1-28. [CrossRef]

57. Gallego-Ayala, J.; Gómez-Limón, J.A.; Arriaza, M. Irrigation water pricing instruments: A sustainability assessment. Span. J. Agric. Res. 2011, 9, 981-999. [CrossRef]

58. Komives, K.; Foster, V.; Halpern, J.; Wodon, Q. Water, Electricity, and the Poor; World Bank: Washington, DC, USA, 2005.

59. UNDP. Beyond Scarcity: Power, Poverty and the Global Water Crisis; United Nations Development Programme: New York, NY, USA, 2006.

60. Mesa-Jurado, M. Valoración del Agua de Riego y Disposición a Pagar por la Mejora de la Garantía de Suministro. El caso del olivar de Regadío. Ph.D. Thesis, University of Cordoba, Cordoba, Spain, 2011.

61. Giannoccaro, G.; Prosperi, M.; Zanni, G. Assessing the Impact of Alternative Water Pricing Schemes on Income Distribution. J. Agric. Econ. 2010, 61, 527-544. [CrossRef]

62. Gómez-Limón, J.A.; Riesgo, L. Irrigation water pricing: Differential impacts on irrigated farms. Agric. Econ. 2004, 31, 47-66. [CrossRef]

63. Interwies, E.; Dworak, T.; Görlach, B.; Best, A. WFD and Agricultural Linkages at the EU Level; Final Report about Incentive Water Pricing and Cost Recovery in the WFD: Elements for Linking EU Agricultural and Water Policies; Ecologic-Institute for International and European Environmental Policy: Berlin, Germany, 2006.

64. Riegels, N.; Pulido-Velazquez, M.; Doulgeris, C.; Sturm, V.; Jensen, R.; Møller, F.; Bauer-Gottwein, P. Systems Analysis Approach to the Design of Efficient Water Pricing Policies under the EU Water Framework Directive. J. Water Resour. Plan. Manag. 2013, 139, 574-582. [CrossRef]

65. Rutz, C.; Dwyer, J.; Schramek, J. More new wine in the same old bottles? The evolving nature of the CAP reform debate in Europe, and prospects for the future. Sociol. Rural. 2014, 54, 266-284. [CrossRef]

(C) 2018 by the author. Licensee MDPI, Basel, Switzerland. This article is an open access article distributed under the terms and conditions of the Creative Commons Attribution (CC BY) license (http://creativecommons.org/licenses/by/4.0/). 